\title{
Involvement of PPAR $\gamma$ in the antitumoral action of cannabinoids on hepatocellular carcinoma
}

\author{
D Vara ${ }^{1}$, C Morell ${ }^{1}$, N Rodríguez-Henche ${ }^{1}$ and I Diaz-Laviada* ${ }^{* 1}$
}

Cannabinoids exert antiproliferative effects in a wide range of tumoral cells, including hepatocellular carcinoma (HCC) cells. In this study, we examined whether the PPAR $\gamma$-activated pathway contributed to the antitumor effect of two cannabinoids, 49-tetrahydrocannabinol (THC) and JWH-015, against HepG2 and HUH-7 HCC cells. Both cannabinoids increased the activity and intracellular level of PPAR $\gamma$ mRNA and protein, which was abolished by the PPAR $\gamma$ inhibitor GW9662. Moreover, genetic ablation with small interfering RNA (siRNA), as well as pharmacological inhibition of PPAR $\gamma$ decreased the cannabinoid-induced cell death and apoptosis. Likewise, GW9662 totally blocked the antitumoral action of cannabinoids in xenograft-induced HCC tumors in mice. In addition, PPAR $\gamma$ knockdown with siRNA caused accumulation of the autophagy markers LC3-II and p62, suggesting that PPAR $\gamma$ is necessary for the autophagy flux promoted by cannabinoids. Interestingly, downregulation of the endoplasmic reticulum stress-related protein tribbles homolog 3 (TRIB3) markedly reduced PPAR $\gamma$ expression and induced p62 accumulation, which was counteracted by overexpression of PPAR $\gamma$ in TRIB3-knocked down cells. Taken together, we demonstrate for the first time that the antiproliferative action of the cannabinoids THC and JWH-015 on HCC, in vitro and in vivo, are modulated by upregulation of PPAR $\gamma$-dependent pathways.

Cell Death and Disease (2013) 4, e618; doi:10.1038/cddis.2013.141; published online 2 May 2013

Subject Category: Cancer Metabolism

Hepatocellular carcinoma ( $\mathrm{HCC}$ ) is the most frequent primary solid tumor of the liver, and it is estimated to account for $5 \%$ of all malignant neoplasias. ${ }^{1,2}$ Its aggressiveness and extensive dissemination lead to poor patient prognosis. Although there has been a great research effort made in order to come up with efficient therapeutic strategies, the incidence and mortality of HCC have increased in the United States and Europe in the past decade and therefore innovative research findings are necessary to understand the etiology of cancer and to improve the treatment and survival of patients.

Cannabinoids are bioactive lipids that have been shown to modulate many physiological and pathological conditions. In particular, it has been previously described that cannabinoids arrest cell proliferation, reduce cell migration and inhibit angiogenesis, and therefore, cannabinoid-like compounds offer a therapeutic potential for the treatment of many types of cancer. ${ }^{3-5}$ Although the well-defined cannabinoid receptors are the GPCR receptor types $\mathrm{CB}_{1}$ and $\mathrm{CB}_{2}$, cannabinoids may impact other putative targets such as nuclear receptors PPARs. ${ }^{6,7}$ PPARs are ligand-activated transcription factors, which belong to the nuclear receptor superfamily and mediate several physiological functions, among which the best characterized are lipid metabolism, energy balance and antiinflammation. ${ }^{8}$ There are three PPAR subtypes: alpha, delta (also known as beta) and gamma, all of which have long been known to be expressed in the liver, although at different levels. ${ }^{9}$ PPAR $\gamma$ exists in two major isoforms $\left(\gamma_{1}\right.$ and $\left.\gamma_{2}\right)$ that arise by differential transcription start sites and alternative splicing, ${ }^{10}$ albeit PPAR $\gamma_{1}$ expression is very low in most tissues including the liver. PPAR $\gamma$ is involved in liver lipid synthesis and storage, and despite its relatively low levels in healthy liver it has a relevant role in several liver pathologies such as liver steatosis, fibrosis and HCC. Although the role of PPAR $\gamma$ in the development of liver diseases with different aetiologies has led to controversial results, there is a general consensus about the fact that increased PPAR $\gamma$ activity can counteract the occurrence and progression of cancer in the liver. Several PPAR $\gamma$ ligands have been shown to reduce $\mathrm{HCC}$ cell proliferation and migration through PPAR $\gamma$ activation. ${ }^{11-15}$ Moreover, recent findings using PPAR $\gamma$ knockout mice suggest that PPAR $\gamma$ reduces $\mathrm{HCC}$ carcinogenesis and acts as a tumor-suppressor gene in the liver. ${ }^{16}$ Many current lines of evidence indicate that there is a cross talk between death signalling pathways and PPAR $\gamma$ activity in several cancer cell types. ${ }^{17}$ It has been demonstrated that the synthetic cannabinoid WIN 55,212-2 (WIN) induces apoptosis in the HCC HepG2 cell line, which is associated with an increase in PPAR $\gamma$ expression. ${ }^{18}$ We have previously described that the cannabinoids $\Delta^{9}$-tetrahydrocannabinol (THC), the main psychoactive component of the Cannabis sativa plant, and JWH-015, a synthetic selective ligand of $\mathrm{CB}_{2}$, exert antiproliferative effects and induce autophagy on the HCC cell lines HepG2 and HuH-7. ${ }^{19}$ As cannabinoids have well-known palliative effects on some cancer-associated and

\footnotetext{
${ }^{1}$ Biochemistry and Molecular Biology Unit, Department of System Biology, School of Medicine, University ofAlcala, 28871 Madrid, Spain

*Corresponding author: I Diaz-Laviada, Biochemistry and Molecular Biology Unit, Department of System Biology, School of Medicine, University of Alcala, 28871 Alcala de Henares, Madrid, Spain. Tel: +34 91 8855141; Fax: +34 91 8854585; E-mail: ines.diazlaviada@uah.es

Keywords: cannabinoids; THC; JWH-015; PPAR $\gamma ;$ TRIB3; HepG2

Abbreviations: Akt, serine-threonine kinase Akt; AMPK, adenosine monophosphate-activated kinase; CB1, cannabinoid receptor 1; CB2, cannabinoid receptor 2; HCC, hepatocellular carcinoma; HepG2, human hepatocellular liver carcinoma cell line; HuH-7, hepatocellular carcinoma cells; LC3, microtubule-associated protein 1 light chain 3a; THC, $\triangle 9$-tetrahydrocannabinol; mTOR, mammalian target of rapamycin; TRIB3, tribbles homolog 3; TRO, Troglitazone

Received 04.9.12; revised 18.3.13; accepted 25.3.13; Edited by Munoz-Pinedo
} 

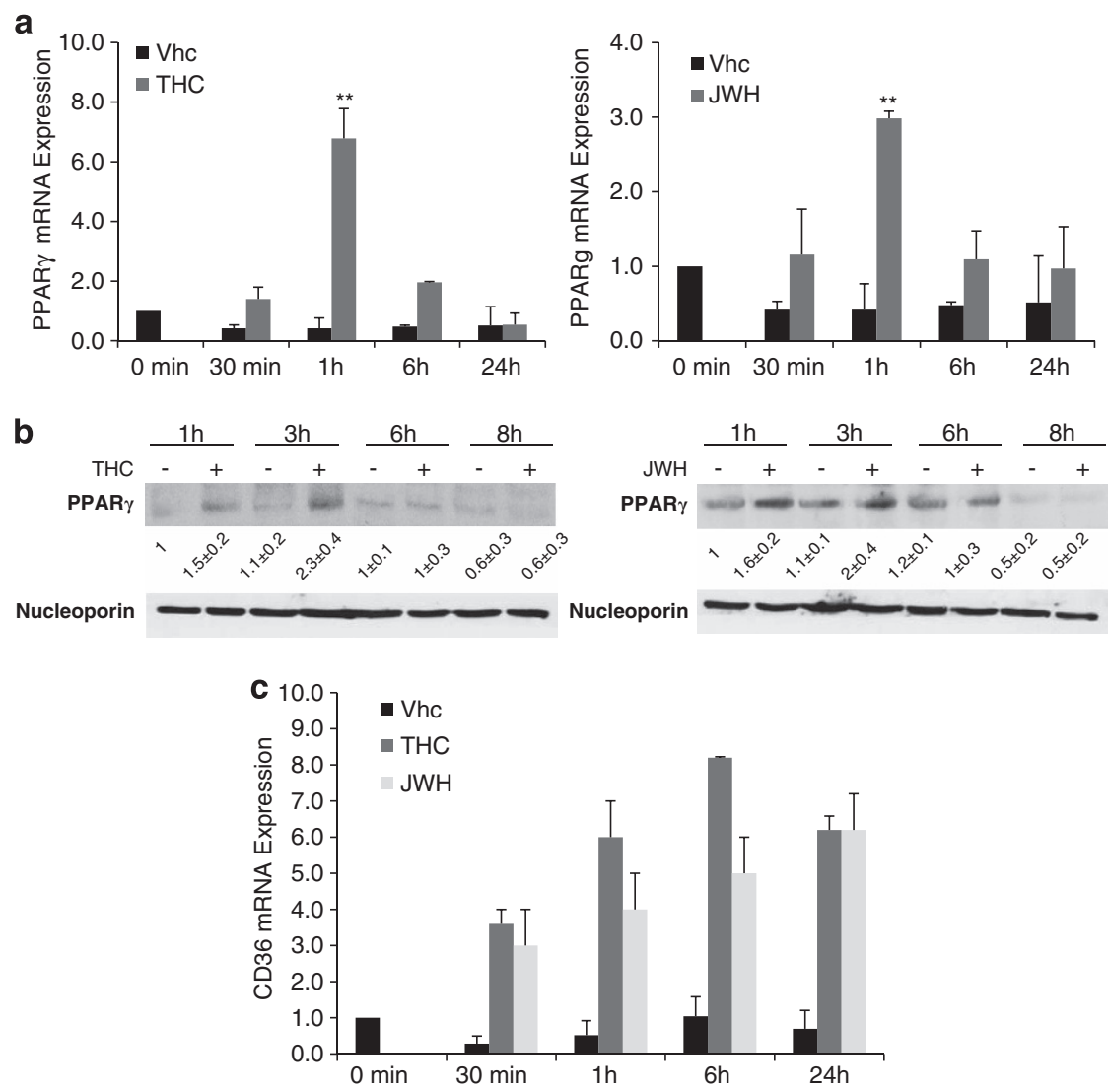

Figure 1 Cannabinoid-induced PPAR $\gamma$ increase in HCC cells. (a) HepG2 cells were treated with $\Delta^{9}$-tetrahydrocannabinol $(8 \mu \mathrm{M})$ or JWH-015 (8 $\left.\mu \mathrm{M}\right)$ for different times and PPAR $\gamma$ mRNA levels were determined by quantitative PCR. Results are shown as the mean \pm S.E. $\left(n=5 ;{ }^{* *} P<0.01\right.$ as compared with control cells by Student's $t$-test). (b) HepG2 cells were incubated either with THC $(8 \mu \mathrm{M})$ or with JWH-015 $(8 \mu \mathrm{M})$, and PPAR $\gamma$ protein levels were detected by western blot. Nucleoporin levels are shown as loading control. The image is representative of three different experiments performed in duplicate. (c) HepG2 cells were incubated with THC $(8 \mu \mathrm{M})$ or JWH-015 $(8 \mu \mathrm{M})$ for different times and CD36 mRNA levels were determined by quantitative PCR

chemotherapy-related symptoms, and they are being therapeutically used for this purpose, it is necessary to further study the antitumoral properties of cannabinoids for a better management of those compounds. In this study, we investigated whether PPAR $\gamma$ is involved in the antiproliferative effect of cannabinoids on HCC cells and its relationship with the previously identified signalling pathways.

\section{Results}

The cannabinoids THC and JWH-015 activate PPAR $\gamma$ in HCC cells. To investigate the role of PPAR $\gamma$ in the mechanism of action of cannabinoids on HCC cells, we treated HepG2 cells with the cannabinoids $\mathrm{THC}$ and JWH015, after which PPAR $\gamma$ expression was examined using RT-PCR and western blot. As shown in Figure 1a, there was a peak of PPAR $\gamma$ mRNA at 1-h treatment with both cannabinoids and a further decline at $24 \mathrm{~h}$. Likewise, PPAR $\gamma$ protein expression increased until $3 \mathrm{~h}$ and then decreased at $8 \mathrm{~h}$ (Figure 1b). As a further proof of PPAR $\gamma$ induction, we measured the PPAR $\gamma$ target CD36 to confirm PPAR $\gamma$ activation. As shown in Figure 1c, THC and JWH-015 produced an increase in CD36 mRNA levels with a peak at $6 \mathrm{~h}$ of treatment. Lipid accumulation in liver cells is considered an indicator of PPAR $\gamma$ activation. Therefore, we measured neutral lipid content in HepG2 and HUH-7 cells by Oil Red O staining. Neutral lipid accumulated in both HepG2 and $\mathrm{HUH}-7$ cells after THC and JWH-015 treatment. The increase in Oil Red $\mathrm{O}$ staining was prevented by pretreatment with the PPAR $\gamma$ antagonist GW9662, confirming the involvement of PPAR $\gamma$ in neutral lipid accumulation and PPAR $\gamma$ activation after cannabinoids treatment (Figure 2a). Confocal microscopy of HepG2 cells treated with THC and JWH-015 also showed a neutral lipid accumulation within the cell (Figure 2c). Therefore, these data demonstrated that cannabinoids treatment activates PPAR $\gamma$ in HCC cells.

The activation of PPAR $\gamma$ by cannabinoids may be performed by direct binding to the receptor or by intracellular signalling cascades that may lead indirectly to PPAR $\gamma$ activation. The mechanism of action of THC on PPAR $\gamma$ has been extensively studied by O'Sullivan and Kendall, ${ }^{20}$ but it is unknown if JWH-015 can activate PPAR $\gamma$ directly. To investigate whether JWH-015 joined PPAR $\gamma$, we performed a binding assay using HeLa cells with a reporter luciferase gene. However, JWH-015-induced PPAR $\gamma$ activation was not due to an agonist activity of the compound, as JWH-015 was not able to bind to the ligand-binding domain of PPAR $\gamma$ in the in vitro assay (Figure $2 \mathrm{c}$ ), suggesting that PPAR $\gamma$ activation 


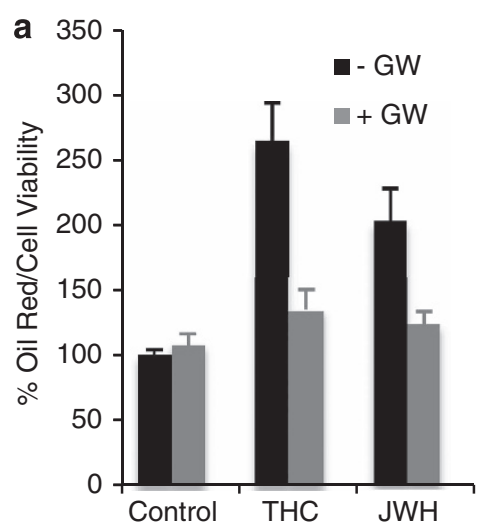

b
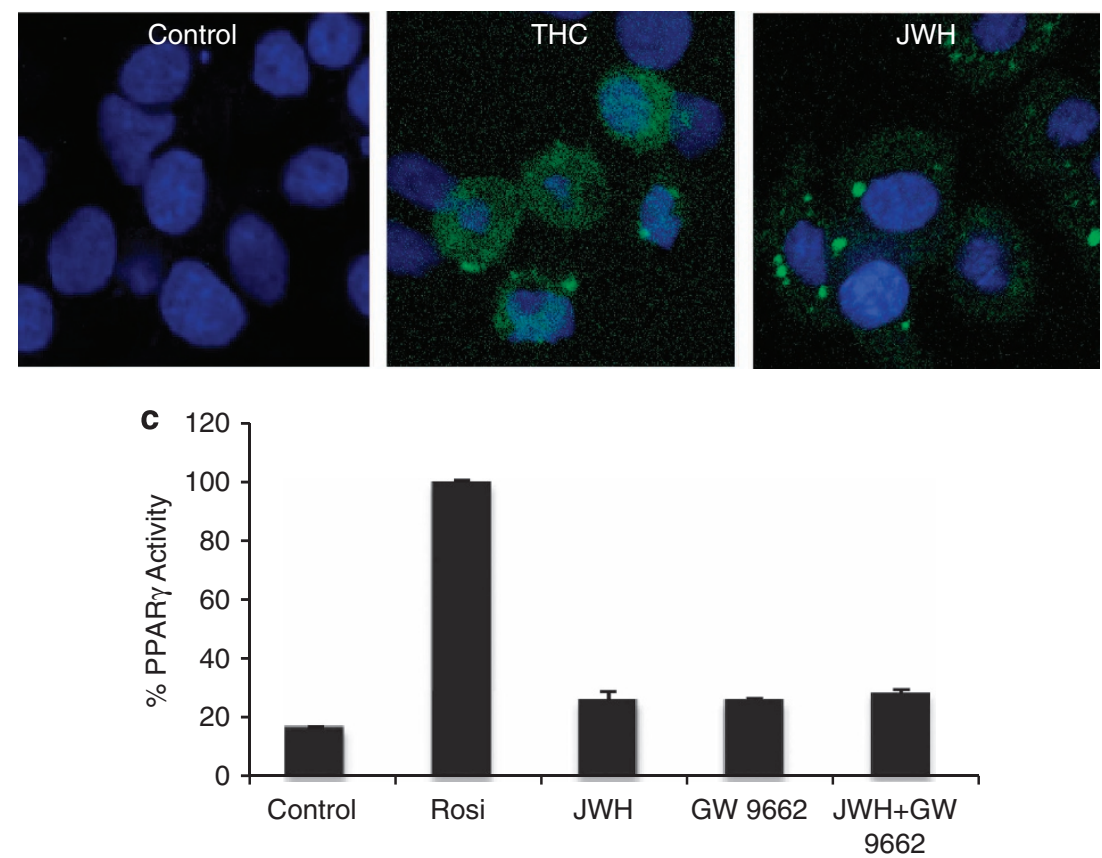

Figure $2 \Delta^{9}$-Tetrahydrocannabinol and JWH-015 increase intracellular neutral lipid content in HCC cells. (a) HepG2 cells were incubated in the presence of increasing concentrations of THC or JWH-015 for $24 \mathrm{~h}$, and intracellular neutral lipid content was measured by Oil Red $\mathrm{O}$ stain as indicated in the Materials and Methods section, and normalized to cell viability performed by MTT. Data are the mean \pm S.E. of three different experiments performed in duplicate. (b) HepG2 cells were treated with $8 \mu \mathrm{M}$ THC or $8 \mu \mathrm{M} \mathrm{JWH}-015$ for $24 \mathrm{~h}$ and neutral lipid was detected by confocal immunofluorescence. Nuclei were stained with $4^{\prime}, 6$-diamidino-2-phenylindole. The image is representative

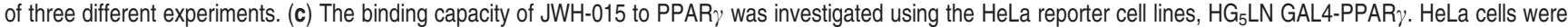
treated with JWH-015 $(8 \mu \mathrm{M})$ and binding to PPAR $\gamma$ was estimated by luciferase activity (relative light units normalized against the reference compound BRL49653) and expressed as percentage relative to $1 \mu \mathrm{M}$ of the classical agonist Rosiglitazone (Rosi)

must be happening indirectly through signaling pathways activated by cannabinoids.

AMPK and PPAR $\gamma$ are two independent pathways activated by cannabinoids. We have previously shown that THC and JWH-015 stimulate autophagy on HCC cells through two different pathways: (i) activation of adenosine monophosphate-activated kinase (AMPK) via CaMKKb, and (ii) ER stress with upregulation of tribbles homolog 3 (TRIB3) and subsequent inhibition of the serine-threonine kinase Akt/ mammalian target of rapamycin $\mathrm{C}$ (Akt/mTORC1) axis. ${ }^{19}$ Furthermore, AMPK has been shown to participate in modulating the activity of PPAR $\gamma,{ }^{21}$ thus providing a possible mechanism for cross talk between the signaling pathways activated by cannabinoids. PPAR $\gamma$ phosphorylation by AMPK represses both the ligand-dependent and independent transactivating function of the receptor. Therefore, we examined whether the activities of these molecules by cannabinoids were coordinately regulated. To investigate the relationship between these two pathways, we knocked down AMPK and measured PPAR $\gamma$ levels after cell treatment with THC and JWH-015. Both cannabinoids, THC and JWH-015, were able to increase PPAR $\gamma$ levels even when AMPK was absent (Figure 3a). These findings indicate that AMPK is not necessary for PPAR $\gamma$ induction by cannabinoids. Moreover, PPAR $\gamma$ is not necessary for AMPK activation by cannabinoids, as downregulation of PPAR $\gamma$ did not reverse the increase in AMPK phosphorylation produced by THC or 
JWH-015 (Figure 3b). Therefore, these data suggest that AMPK and PPAR $\gamma$ are two independent pathways activated by cannabinoids in HCC.

The TRIB3 protein regulates PPAR $\gamma$ expression in HCC cells. To investigate whether PPAR $\gamma$ induction was associated with the second mechanism by which cannabinoid induced cell death (ER stress/Akt/mTORC1 axis), we

a

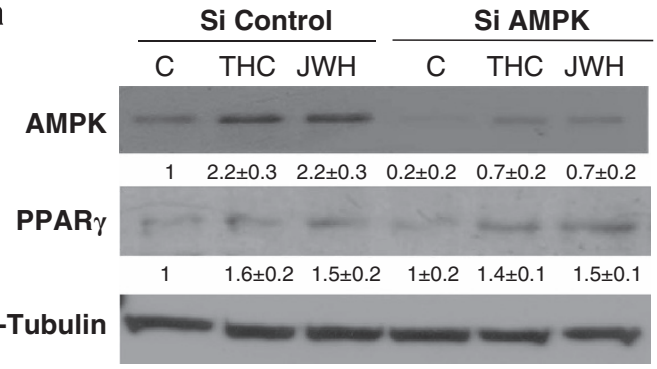

b

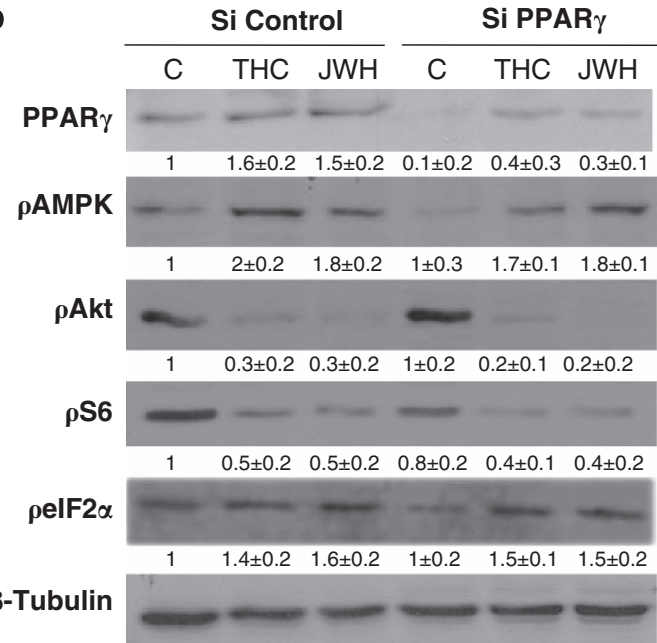

C

Si Control

Si TRIB3

$\begin{array}{llllll}\text { C THC JWH } & \text { C THC JWH }\end{array}$

PPAR $\gamma$

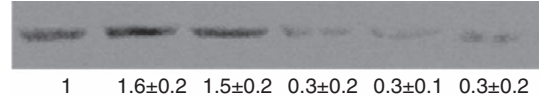

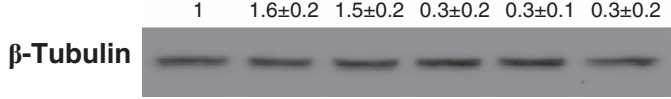

Si TRIB3

Si Control

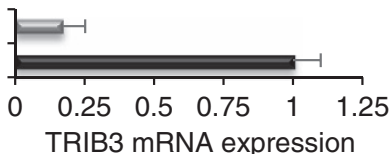

TRIB3 mRNA expression

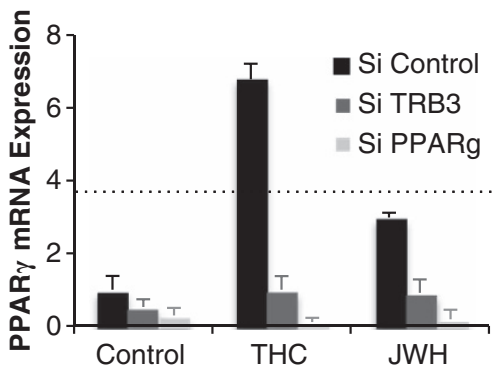

analysed this pathway in cells in which PPAR $\gamma$ was genetically blocked. However, PPAR $\gamma$ knockdown did not modify the inhibition of the Akt pathway and S6 phosphorylation or the increase in elF2 $\alpha$ phosphorylation, which we had previously reported to be modified after cannabinoids treatment (Figure 3b).

The intracellular adaptor TRIB3, a human homolog of Drosophila tribbles, has been found to interact with a variety of signalling molecules to regulate diverse cellular functions including cell proliferation, migration and morphogenesis by participating in protein complex assembly. In the liver, it functions as a negative regulator of the serine-threonine kinase Akt. We have previously shown that TRIB3 links cannabinoid-induced ceramide production and endoplasmic reticulum stress with Akt inhibition and autophagy in HCC cells. ${ }^{19}$ Recent research has shown that in 3T3-L1 adipocytes TRIB3 interacts with PPAR $\gamma$ to modulate its transcriptional activity. ${ }^{22}$ To investigate the role of TRIB3 in the action mechanism of cannabinoids, HCC cells were transfected with selective TRIB3 siRNA, treated with THC or JWH-015, and examined for PPAR $\gamma$ protein and mRNA expression. As shown in Figure 3c, when TRIB3 was knocked down, levels of PPAR $\gamma$ were virtually undetectable, both in control cells and in cannabinoid-treated cells, being even more effective than $\operatorname{PPAR} \gamma$ silencing. This means that TRIB3 is necessary for PPAR $\gamma$ expression and suggests a new PPAR $\gamma$ regulatory pathway to be explored in further research.

PPAR $\gamma$ contributes to cannabinoid-induced autophagy. Owing to recent data about the involvement of PPAR $\gamma$ in autophagy $^{23,24}$ and as this process is necessary for the antitumoral action of cannabinoid, ${ }^{19,25}$ we wondered whether $\operatorname{PPAR} \gamma$ receptor might also have a role in the autophagy induced by cannabinoids on HCC cells. To investigate this effect, we analyzed LC3-II levels, a hallmark of autophagy, in cannabinoid-treated cells. As shown in Figure 4, THC and JWH-015 induced an increase in LC3II, as was expected, measured by western blot (a) or confocal microscopy (b). Surprisingly, knocking down of PPAR $\gamma$ increased LC3II even in the control cells. Likewise, cells treated with cannabinoids showed higher LC3II levels when PPAR $\gamma$ was knocked down than when cells were transfected with the control siRNA. To investigate whether this increase was caused by an augmented activation of autophagy, levels of the signal adaptor protein p62, an autophagosome cargo that is

Figure 3 TRIB3 is required for PPAR $\gamma$ activation. (a) HepG2 cells were transfected with control siRNA (siControl) or AMPK selective siRNA (siAMPK) and incubated with THC $(8 \mu \mathrm{M})$ or JWH-015 $(8 \mu \mathrm{M})$ for $3 \mathrm{~h}$, after which levels of PPAR $\gamma$ were detected by western blot. (b) HepG2 cells were transfected with control siRNA (siControl) or PPAR $\gamma$ selective siRNA (siPPAR $\gamma$ ) and incubated with THC $(8 \mu \mathrm{M})$ or JWH-015 $(8 \mu \mathrm{M})$ for $24 \mathrm{~h}$, after which levels of phosphorylated forms of AMPK, AKT, S6 and elF2 $\alpha$ were determined by western blot. (c) HepG2 cells were transfected with control siRNA (siControl) or TRIB3 selective siRNA (siTRIB3) and incubated with THC $(8 \mu \mathrm{M})$ or JWH-015 $(8 \mu \mathrm{M})$ for $3 \mathrm{~h}$, after which PPAR $\gamma$ levels were determined by western blot and quantitative PCR. Levels of TRIB3 mRNA measured by quantitative PCR in siControl and siTRIB3-treated cells are shown under the western blot. Data are the mean \pm S.D. of two experiments performed by triplicate. Tubulin levels are shown as a loading control of western blots. The images are representative of three different experiments 
a

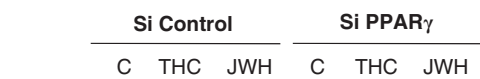

PPAR $\gamma$

C THC JWH C THC JWH

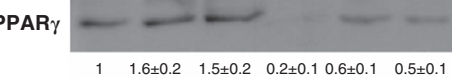

p62

$\begin{array}{lllll}16 \pm 0.2 & 15 \pm 0.2 & 0.2+0.10 .6 \pm 0.1 & 0.5 \pm 0.1\end{array}$

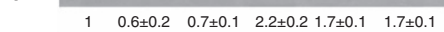

$\begin{array}{lllll}\text { LC3 I } & = & = & =\end{array}$

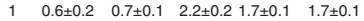

LAMP-2

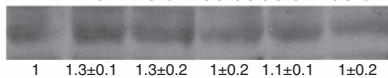

Procathepsin L

Cathepsin L

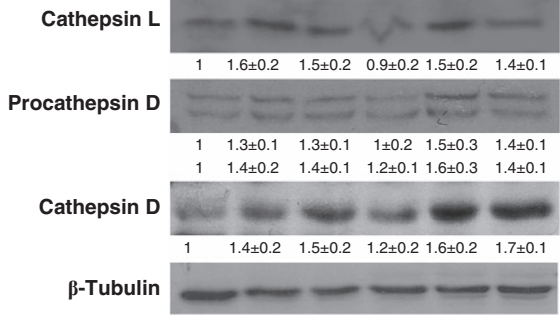

C
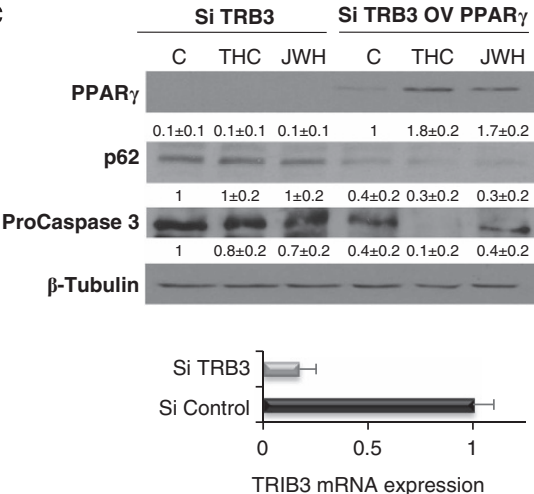

b

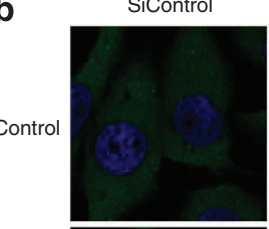

SiPPAR $\gamma$

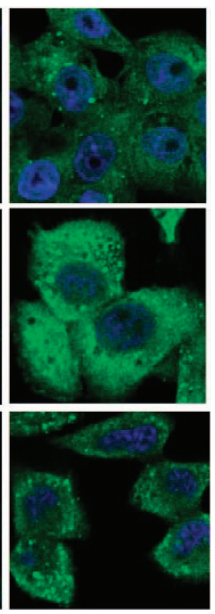

d

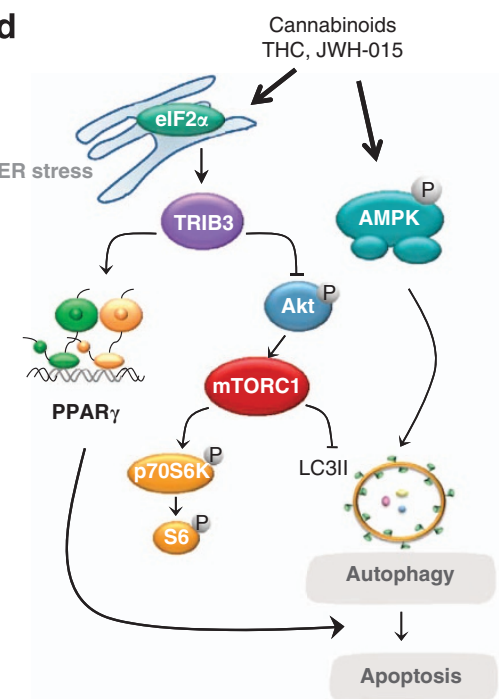

Figure 4 PPAR $\gamma$ participates in autophagy induction. (a) HepG2 cells were transfected with siRNA control or selective for PPAR $($ siControl or siPPAR $\gamma$ ) and treated with THC $8 \mu \mathrm{M}$ or JWH-015 $8 \mu \mathrm{M}$ and PPAR $\gamma$ and p62 levels, microtubule-associated protein 1 light chain 3a non-lipidated (LC3-I) and lipidated (LC3-II) forms, LAMP-2 protein, as well as procathepsin and cathepsil $\mathrm{L}$, procathepsin and cathepsin $\mathrm{D}$, were detected by western blot. Tubulin levels are shown as loading control. A representative western blot of three different experiments is shown. (b) HepG2 cells were transfected with siRNA control or selective for PPAR $\gamma$ (siControl or siPPAR $\gamma$ ), treated with THC $8 \mu \mathrm{M}$ or JWH$0158 \mu \mathrm{M}$ for $24 \mathrm{~h}$, and LC3 was detected by confocal immunofluorescence. Nuclei were stained with 4',6-diamidino-2-phenylindole. (c) HepG2 cells were transfected with scramble (SiControl) or TRIB3 siRNA (SiTRIB3). At the same time, cells were transfected with an empty vector or PPAR $\gamma$ overexpression vector as indicated in the Materials and Methods section. After $48 \mathrm{~h}$, cells were treated with DMSO (control), THC $8 \mu \mathrm{M}$ or JWH $8 \mu \mathrm{M}$ for $24 \mathrm{~h}$ and PPAR $\gamma$, p62, procaspase 3 and Tubulin were measured by western blot. Images are representative of three different experiments. Levels of TRIB3 mRNA measured by quantitative PCR in siControl and siTRIB3-treated cells are shown under the western blot. (d) Scheme of the proposed mechanism of cannabinoid-induced HCC cell death. Cannabinoid treatment stimulates autophagy via two different mechanisms: (i) activation of AMPK or (ii) upregulation of tribbles homolog 3. TRIB3 induces subsequent inhibition of the serine-threonine kinase Akt/mammalian target of rapamycin $\mathrm{C}(\mathrm{Akt} / \mathrm{mTORC} 1)$ axis or upregulation of PPAR $\gamma$. Stimulation of autophagy by cannabinoids leads to HCC apoptosis and cell death

eliminated by autophagy and accumulates when autophagy is deficient, were measured in control RNA-transfected cells and in PPAR $\gamma$ siRNA-transfected cells. As observed in Figure $4 \mathrm{a}$, levels of p62 protein increased when PPAR $\gamma$ was silenced in control cells compared with cannabinoidtreated cells. These results indicate that in PPAR $\gamma$-depleted cells, autophagy is not active, but it is blocked after autophagosome formation, and then p62 accumulates. If TRIB3 is responsible for PPAR $\gamma$ expression, then PPAR $\gamma$ overexpression in TRIB3-depleted cells should reverse p62 accumulation. Figure $4 \mathrm{c}$ shows that this is the case, as p62 does not accumulate in TRIB3-silenced cells in which PPAR $\gamma$ overexpression was induced by a mammalian expression vector, indicating that PPAR $\gamma$ is responsible for the autophagosome blockage. Likewise, PPAR $\gamma$ overexpression in TRIB3-silenced cells restored the caspase 3 cleavage (Figure 4c).

Autophagosome accumulation can occur for two reasons: (i) autophagosomes are not fused with lysosomes or/and (ii) lysosomes do not work correctly. As there are no data about the participation of PPAR $\gamma$ in the autophagosome-lysosome fusion, but there are findings showing that PPAR $\gamma$ regulates Iysosomal proteases, ${ }^{26,27}$ we decided to investigate this option. Lysosomes are the key degradative compartments of 
HepG2
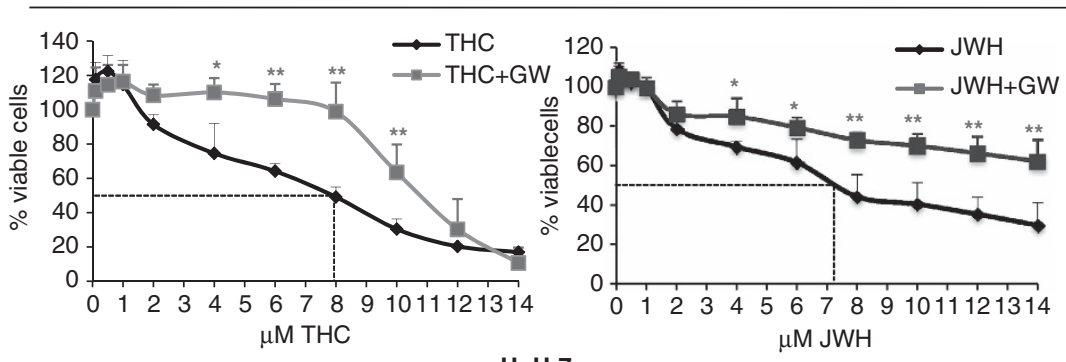

HuH-7
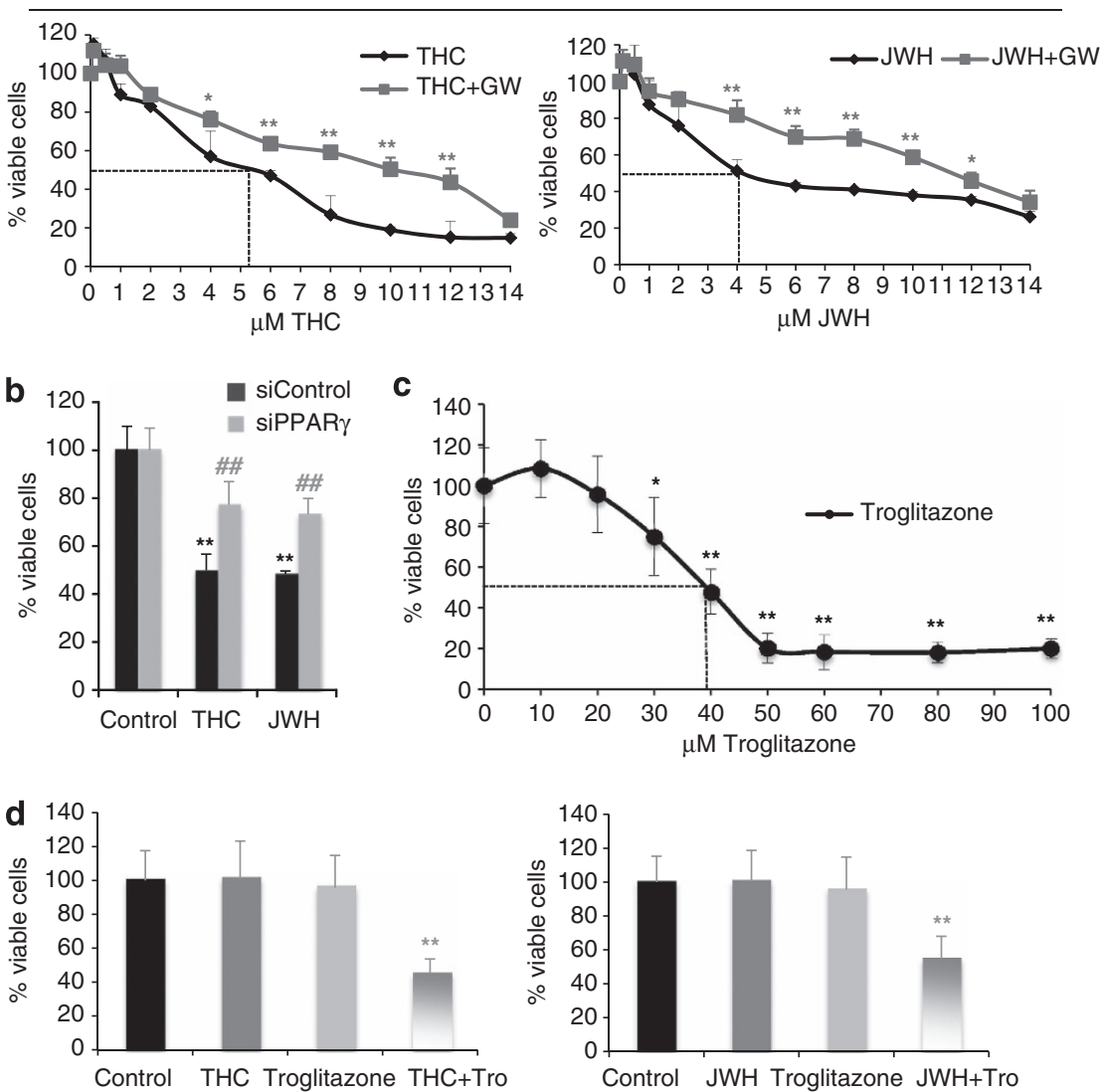

Figure 5 PPAR $\gamma$ is involved in cannabinoid-induced cell death. (a) HepG2 or HuH7 cells were incubated with different doses of THC or JWH-015 for $48 \mathrm{~h}$ in the presence or absence of $3 \mu \mathrm{M}$ GW9662 (GW) and cell viability was assayed by MTT. Results are shown as the mean \pm S.D. of three different experiments, each performed in triplicate. ${ }^{*} P<0.05$ and ${ }^{*} P<0.01$ as compared with cannabinoid-treated cells by Student's $t$-test. (b and $\mathbf{c}$ ) HepG2 cells transfected either with control siRNA or PPAR $\gamma$-selective siRNA (siPPAR $\gamma$ ) were incubated with $8 \mu \mathrm{M} \mathrm{THC}$ or $8 \mu \mathrm{M}$ JWH-015 (JWH) for $48 \mathrm{~h}$ and cell viability was assayed by MTT. Results are shown as the mean \pm S.D. of five different experiments $\left({ }^{* *} P<0.01\right.$ as compared with control cells and ${ }^{\# \#} P<0.01$ as compared with siControl cannabinoid-treated cells by Student's $t$-test). (c) HepG2 cells were incubated with different doses of Troglitazone for $48 \mathrm{~h}$ and cell viability was assayed by MTT. (d) HepG2 cells were incubated with THC ( $2 \mu \mathrm{M})$, JWH $(2 \mu \mathrm{M})$, Troglitazone $(20 \mu \mathrm{M})$ or THC plus Troglitazone for $48 \mathrm{~h}$ and cell viability was assayed by MTT

the cell, because they are acidic organelles filled with hydrolases. Among the lysosomal hydrolases, proteases, especially cathepsins, have a major role. Similar to other proteases, the cathepsins are synthesized as inactive proenzymes and are activated by proteolytic removal of the $\mathrm{N}$-terminal propeptide. As shown in Figure $4 \mathrm{a}, \mathrm{THC}$ and JWH015 increased the levels of cathepsines $D$ and $L$ (both inactive and active forms). However, PPAR $\gamma$ knockdown did not modify these increases, suggesting that PPAR $\gamma$ does not regulate cathepsin $L$ or $D$ in this model. Cysteine cathepsins are optimally active in a slightly acidic $\mathrm{pH}$, and are mostly unstable at neutral $\mathrm{pH}$. When cathepsins are outside the lysosomes or if there is no acidic $\mathrm{pH}$ within the lysosome, they can be relatively rapidly inactivated and proenzymes accumulate. ${ }^{28}$ As SiControl and SiPPAR $\gamma$-untreated or cannabinoid-treated cells had a right cleavage of these proteases and the same level of the lysosomal marker LAMP-2, we can conclude that lysosomes work correctly, suggesting that the reason for autophagosome accumulation is not lysosome failure. This is in concordance with the observation that PPAR $\gamma$ silencing causes an accumulation of LC3 even in control cells (Figures $4 a$ and b). Therefore, we can conclude that in HCC cells cannabinoids induce autophagy through PPAR $\gamma$ activation (summarized in Figure 4d). 


\section{Control}

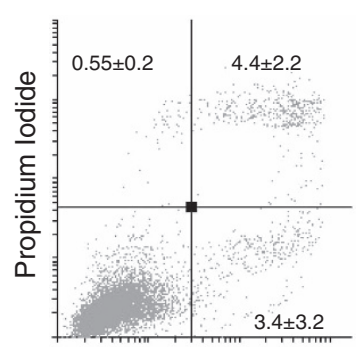

Anexin V-FITC

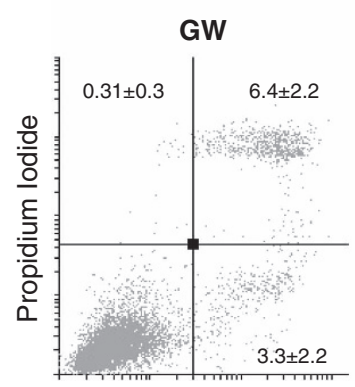

Anexin V-FITC
THC $8 \mu \mathrm{M}$

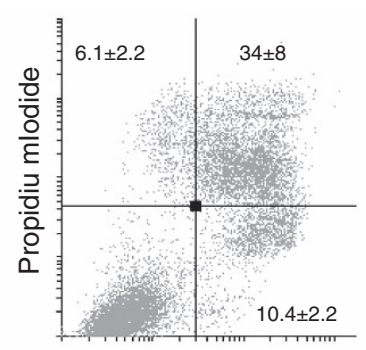

Anexin V-FITC

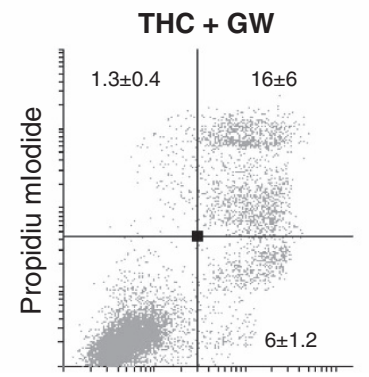

Anexin V-FITC

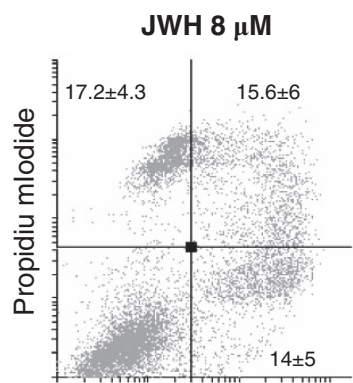

Anexin V-FITC

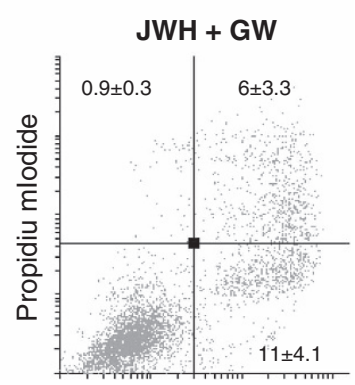

Anexin V-FITC

Figure 6 Cannabinoids induce apoptosis in HepG2 and HUH-7 cells. Representative plots of Annexin V-FITC/IP staining of HepG2 cells incubated with $8 \mu \mathrm{M}$ THC or $8 \mu \mathrm{M}$ JWH-015 for $24 \mathrm{~h}$ in the presence or absence of $3 \mu \mathrm{M}$ GW9662 (GW) are shown. Data are the mean \pm S.D. of three different experiments, each performed in duplicate

PPAR $\gamma$ participates in the antiproliferative effect evoked by cannabinoids. It has been recently described that the cannabinoid WIN induces apoptosis through PPAR in HepG2 cells. ${ }^{18}$ Moreover, in previous studies, we demonstrated that cannabinoids induce apoptosis and autophagy in HCC cells and in xenograft tumor models. To investigate the role of PPAR $\gamma$ in the anti-proliferative response exerted by $\mathrm{THC}$ or JWH-015, HCC cells were incubated with increasing doses of both cannabinoids for $48 \mathrm{~h}$ in the presence of the PPAR $\gamma$-selective antagonist GW9669 and cell viability was measured by MTT. Pharmacological inhibition of PPAR $\gamma$ caused a shift of the dose-response curve to the right, thus increasing the IC50 dose in HepG2 and in $\mathrm{HUH}-7$ cells (Figure 5a). Moreover, when HepG2 cells or $\mathrm{HuH}-7$ cells were transfected with PPAR $\gamma$ siRNA, the inhibitory effect of cannabinoids on cell viability was reduced (Figure $5 \mathrm{~b}$ ). As PPAR $\gamma$ agonists have been evaluated as potential antitumoral agents, we decided to test the possible synergic effect between cannabinoids and the PPAR $\gamma$ agonist Troglitazone (TRO) in combinatorial treatment. In agreement with the results obtained by other groups, ${ }^{16,29-33}$ we observed that TRO treatment produced a dose-dependent reduction in cell viability that reached a value of $50 \%$ when $40 \mu \mathrm{M}$ concentrations were used (Figure $5 \mathrm{c}$ ). We therefore selected submaximal doses of Troglitazone $(20 \mu \mathrm{M})$, THC $(2 \mu \mathrm{M})$ and JWH-015 $(2 \mu \mathrm{M})$ to evaluate whether the combined administration of PPAR ligands and cannabinoids enhanced their ability to reduce cell viability. In line with this possibility, combined treatment with low doses of TRO and THC or JWH-015 reduced the viability of HepG2 cells (Figure 5d).

To further investigate the role of PPAR $\gamma$ in cannabinoidinduced cell death, we measured the number of apoptotic
Anexin-V and IP-stained cells by cytometry. Both THC and JWH-015 increased the number of apoptotic cells, which was reduced by pharmacological inhibition of PPAR $\gamma$ with GW9669 (Figure 6). According to this, GW9669 also reduced the cleavage of procaspase 3 induced by cannabinoids (data not shown). These observations support the fact that PPAR $\gamma$ participates in cell death induced by cannabinoids.

PPAR $\gamma$ is involved in the in vivo antitumor properties of cannabinoids. As a further proof for the involvement of PPAR $\gamma$ in the antitumoral action of cannabinoids, we generated tumor xenografts by subcutaneous inoculation of HepG2 cells in nude mice. Mice were treated peritumorally with $\mathrm{THC}$ or $\mathrm{JWH}-015$ alone or in combination with the PPAR $\gamma$ inhibitor GW9662, and tumor size was daily monitored. As shown in Figure 7, THC and JWH-015 significantly reduced the tumor growth rate. However, when tumors were treated with the cannabinoids in the presence of the PPAR $\gamma$ antagonist, the tumor growth was similar to those of the controls. Furthermore, we analyzed PPAR $\gamma$ mRNA expression of HepG2- and HuH-7-derived tumors, and we found that cannabinoid treatment increased PPAR $\gamma$ mRNA levels in both cases (Figure $7 \mathrm{~b}$ ). Thereby, in vivo antitumor effect of cannabinoids in HCC cells depends on PPAR $\gamma$ activation.

\section{Discussion}

The prevalence and severity of HCC is increasing worldwide and prognosis of HCC patients is still unsatisfactory owing to the high rate of recurrence and metastasis. Therefore, the improvement of therapeutic strategies for HCC patients is critical for the management of HCC. The active ingredients of 

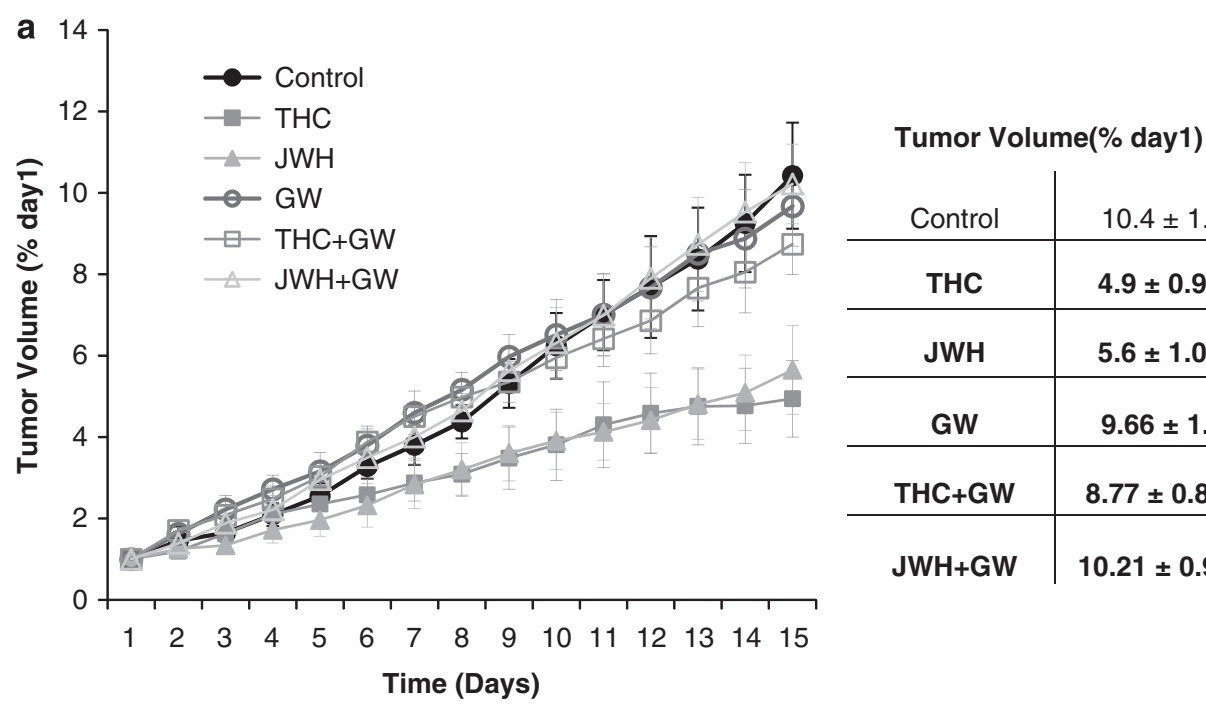

\begin{tabular}{c|c} 
Control & $10.4 \pm 1.3$ \\
\hline THC & $4.9 \pm 0.9^{\star *}$ \\
\hline JWH & $5.6 \pm 1.0^{\star *}$ \\
\hline GW & $9.66 \pm 1.3$ \\
\hline THC+GW & $\mathbf{8 . 7 7} \pm 0.8 \# \#$ \\
\hline JWH+GW & $10.21 \pm 0.9 \# \#$
\end{tabular}
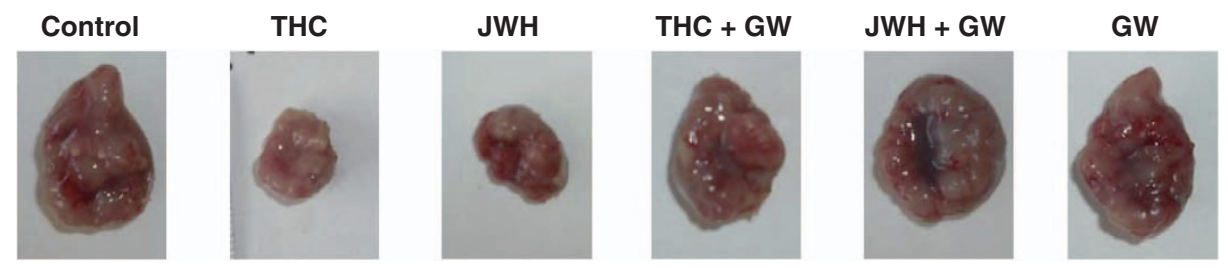

b

HepG2-derived tumors

HuH-7-derived tumors
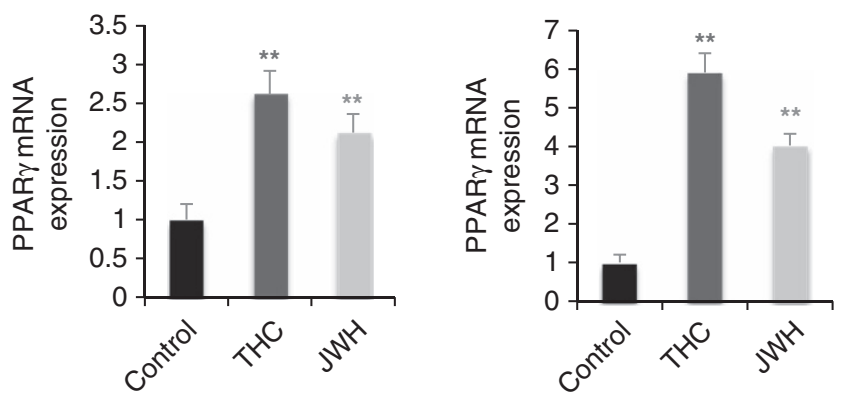

Figure 7 PPAR $\gamma$ is required for the in vivo antitumoral action of THC and JWH-015 on hepatocellular carcinoma tumor xenografts. (a) Athymic nude mice injected s.c. in the right flank with HepG2 cells were daily treated during 15 days with vehicle (control) (filled circles), $15 \mathrm{mg} / \mathrm{kg} \mathrm{THC} \mathrm{(filled} \mathrm{squares),} 1.5 \mathrm{mg} / \mathrm{kg} \mathrm{JWH}-015$ (filled triangles), vehicle plus $1 \mathrm{mg} / \mathrm{kg}$ GW9662 (open circles), $15 \mathrm{mg} / \mathrm{kg} \mathrm{THC} \mathrm{plus} 1 \mathrm{mg} / \mathrm{kg}$ GW9662 (open squares) or $1.5 \mathrm{mg} / \mathrm{kg}$ JWH-015 plus $1 \mathrm{mg} / \mathrm{kg}$ GW9662 (open triangles). Tumor growth curves and final tumor volumes after administration of the treatments are shown. Results represent the mean $\pm \mathrm{S}$.E. of eight mice in each group. ${ }^{* *} P<0.01$ versus control and ${ }^{\# \#} P<0.01$ versus cannabinoid-treated tumors compared by Student's $t$-test. A representative image of the dissected tumors after the treatments is shown. (b) Levels of PPAR $\gamma$ mRNA were detected in the dissected tumor by quantitative PCR. ${ }^{*} P<0.01$ versus control compared by Student's $t$-test

Cannabis sativa plant, as well as their synthetic analogues, emerge nowadays as new anticancer drugs as they exert antitumor properties in a wide range of tumor cell types including HCC cells. During the past few years, much effort has been taken to understand the molecular mechanisms involved in the antitumoral action of cannabinoids. We have recently published that $\mathrm{THC}$ and $\mathrm{JWH}-015$ induce autophagy in HCC cells by activating the AMPK pathway. ${ }^{19}$ In this study, we report the involvement of PPAR $\gamma$ activation in the anticancer effect of cannabinoids. We show that both THC and JWH-015 increase mRNA and protein levels of PPAR $\gamma$ in a time-dependent fashion and induce PPAR activation in vitro. The activation of PPAR $\gamma$ is not produced by direct binding of cannabinoids to PPAR $\gamma$. It has been shown that PPAR $\gamma$ may be phosphorylated by different kinases including AMPK, which can modulate PPAR $\gamma$ activity. ${ }^{21}$ As we had previously observed that cannabinoids induce AMPK activation in HCC cells, we wonder whether AMPK was responsible for cannabinoid-induced PPAR $\gamma$ activation. However, genetic downregulation of AMPK did not have any effect on PPAR $\gamma$ induction exerted by cannabinoids. Moreover, genetic inhibition of PPAR $\gamma$ did not have any effect on AMPK phosphorylation or Akt/mTOR/S6 axis activation in cannabinoid-treated cancer cells, suggesting that PPAR $\gamma$ did not have a role in those pathways. Therefore, although modulation of both AMPK and PPAR $\gamma$ signalling might be responsible for the antiproliferative effect of cannabinoids, a cross talk between them was not found in our study (summarized in Figure 4d). 
Our results are in contrast with recent research showing that activation of AMPK inhibits transcriptional activity of PPAR $\gamma$ in HepG2 cells. ${ }^{34}$ However, in this study, the effects of AMPK did not appear to be mediated through effects on PPAR $\gamma$ binding to DNA and were independent of the kinase activity. ${ }^{34}$

The role of PPAR $\gamma$ in cannabinoid-induced cell death was primarily concluded from the pharmacological blockage of cell death by compound GW9662, a PPAR $\gamma$ selective antagonist, and further confirmed by knockdown of PPAR $\gamma$ expression. In line with this, previous data have evidenced a PPAR $\gamma$ dependent process in WIN-induced HepG2 cell death. ${ }^{18}$ However, in vivo involvement of PPAR $\gamma$ in the cannabinoids' antitumoral action has not been demonstrated before. We show here that pharmacological inhibition of PPAR $\gamma$ in vivo blocks the antitumoral effect of cannabinoids in $\mathrm{HCC}$ xenografts.

The antitumor activity of cannabinoids against HCC cells has been related to the ability of these drugs to induce apoptosis and autophagy. Our results show that when PPAR $\gamma$ is inhibited with GW9662 or genetically knocked down, cannabinoids fail to induce apoptosis. To note, when PPAR $\gamma$ expression is silenced, there is an increase of LC3-II and p62, not only in the cannabinoid-treated cells but even in the control cells. This suggests that when PPAR $\gamma$ is absent, autophagy is blocked after autophagosome formation and therefore LC3II increases and p62 accumulates in the autophagosome because it cannot be further degraded (Figure 4d). Our studies about lysosomal functionality suggest that this organelle operates appropriately, because procathepsins are cleaved and lysosomes are not accumulated. Studies performed by Jiang et al. ${ }^{24}$ in PPAR $\gamma$-deficient mice showed accumulated autophagic vacuoles and upregulated autophagic marker LC3 protein expression. This is in agreement with our observations, which provide a mechanistic link between a $\mathrm{PPAR} \gamma$ receptor and autophagy-essential proteins in mammalian hepatocellular cells. These results are in line with a recent study showing a specific induction of autophagy by PPAR $\gamma$ activation in breast cancer cells. ${ }^{23}$

It has been previously described that cannabinoids cause endoplasmic reticulum stress and increase of the pseudokinase protein TRIB3, which links ER stress to autophagy in cannabinoids' antitumoral action. ${ }^{25,35,36}$ Our results show that when TRIB3 is genetically inhibited, it dramatically decreases the expression of both PPAR $\gamma$ mRNA and protein. Recent studies performed by Takahashi et al. ${ }^{22}$ demonstrated that TRIB3 downregulates PPAR $\gamma$ transcriptional activities by protein-protein interaction in 3T3-L1 adipocytes. Moreover, it has previously been shown that ceramide induces HepG2 cell apoptosis through PPAR $\gamma$ activation. ${ }^{37}$ Our data show that cannabinoid treatment increases phosphorylated-elF2 $\alpha$, an ER stress marker, and that the ER stress-related pseudokinase TRIB3 is necessary for cannabinoid-induced cell death and PPAR $\gamma$ activation. We have also observed that cannabinoids induce ceramide accumulation in HepG2 cells (data not shown), which could link cannabinoid-induced ER stress with inhibition of cell proliferation via PPAR $\gamma$ activation. Here, we provide the first evidence that TRIB3 has a crucial role in regulating cannnabinoid-induced PPAR $\gamma$ overexpression.

\section{Materials and Methods}

Reagents. THC was obtained from THC Pharm GmbH (Frankfurt, Germany) and JWH-015 was purchased from Sigma (St. Louis, MO, USA). Both cannabinoids were dissolved in DMSO. The final concentration of the DMSO in the cell cultures was never $>0.1 \%$. The same quantity of DMSO was added to controls. The anti-PPAR $\gamma$, anti-peiF2 $\alpha$, anti-pAMPK, anti-pS6, anti-pAKT-ser473 and anti-p62 polyclonal antibodies were obtained from Cell Signaling Technology (Danvers, MA, USA). The anti-LC3 polyclonal antibody was obtained from MBL International (Woburn, MA, USA) and procaspase 3, anti-cathepsin D and anticathepsin $L$ were obtained from Santa Cruz Biotechnology (Bergheimer, Heidelberg, Germany). The PPAR $\gamma$ antagonist GW9662, the agonist Troglitazone and all other reagents were purchased from Sigma.

Cell cultures. Human HCC HepG2 cells (ATCC HB-8065, Rockville, MD, USA) and human hepatoma HuH-7 cells (kindly supplied by Dr. Lisardo Boscá, Instituto de Investigaciones Biomédicas Alberto Sols, Madrid, Spain), were maintained in DMEM medium containing $10 \%$ fetal bovine serum, $1 \%$ penicillin/ streptomycin (Invitrogen, Paisley, UK) and $1 \times$ non-essential amino acids. Cells were seeded at a density of $5000 \mathrm{cells} / \mathrm{cm}^{2}$. Sixteen hours post-seeding, medium was changed to $0.5 \%$ FBS medium and experiments were performed $24 \mathrm{~h}$ later, when cells were $80 \%$ confluent.

Quantitative PCR. Total RNA was isolated from cells by Trizol Reagent from Gibco (Invitrogen, Carlsbad, CA, USA), according to the manufacturer's protocol. One microgram total RNA was retrotranscribed to CDNA with the M-MLV Reverse transcriptase kit (Life Technologies, Carlsbad, CA, USA). Real-time quantitative PCR assays were performed using the FastStart Universal Probe Master mix with Rox (Roche Applied Science, Barcelona, Spain), and probes were obtained from the Universal Probe Library Set (Roche Applied Science); TRIB3 sense primer, 5'-GCCACTGCCTCCCGTTCTTG-3'; TRIB3 antisense primer, 5'-GCTGCCTTGCC CGAGTATGA-3'; PPAR $\gamma$ sense primer, 5'-GGCGAGGGCGATCTTGACAGG-3'; PPAR $\gamma$ antisense primer, 5'-TGCGGATGGCCACCTCTTTGC-3'. CD36 sense primer, 5'-AGTCACTGCGACATGATTAATGGT-3́; CD36 antisense primer, 5'-CTG CAATACCTGGCTITTCTC-3'

Western blot. After different treatments according to the experiments, cells were lysed in ice-cold lysis buffer $(50 \mathrm{mM}$ Tris $\mathrm{pH} 7.4,0.8 \mathrm{M} \mathrm{NaCl}, 5 \mathrm{mM} \mathrm{MgCl}$, $0.1 \%$ Triton X-100, $1 \mathrm{mM}$ PMSF, $10 \mu \mathrm{g} / \mathrm{ml}$ soybean trypsin inhibitor, $1 \mu \mathrm{g} / \mathrm{ml}$ aprotinin and $5 \mu \mathrm{g} / \mathrm{ml}$ leupeptin), and cleared by microcentrifugation. Equivalent protein amounts of each sample were separated on SDS-PAGE gels and blotted to PVDF transfer membrane. After blocking with $5 \%$ skim-dried milk, immunoblot analysis was performed followed by enhanced chemoluminescence detection as previously described. ${ }^{38}$

DNA-binding ELISA for activated PPAR $\gamma$ transcription factor. Cells were treated with cannabinoids as explained in the figure legends, and scraped on washing buffer (10 mM Hepes pH 7.9, $1.5 \mathrm{mM} \mathrm{MgCl}_{2}, 10 \mathrm{mM}, \mathrm{KCl}, 1 \mathrm{mM}$ DTT, $0.5 \mathrm{mM}$ PMSF, $5 \mathrm{mM} \mathrm{NaF}, 2 \mu \mathrm{g} / \mathrm{ml}$ leupeptin, $10 \mu \mathrm{g} / \mathrm{ml}$ aprotinin), and then lysed in washing buffer $+0.5 \% \mathrm{NP}-40$ for $30 \mathrm{~min}$ at $4{ }^{\circ} \mathrm{C}$. Then, the nuclear extract was obtained by centrifugation at $15000 \times \mathrm{g}$ for $30 \mathrm{~min}$ at $4^{\circ} \mathrm{C}$. To determine whether the treatment activated PPAR $\gamma, 10 \mu \mathrm{g}$ nuclear extract was incubated in a 96-well plate to which oligonucleotide containing the peroxisome proliferator response element had been immobilized (Active Motif, Rixensart, Belgium). PPARs contained in nuclear extracts bind specifically to this oligonucleotide and are detected through use of an antibody directed against PPAR $\gamma$. Addition of a secondary antibody conjugated to horseradish peroxidase provides a sensitive colorimetric readout that is quantified by spectrophotometry. Unspecific binding is monitored by competition with an oligonucleotide containing the consensus PPAR $\gamma$ response element sequence, according to the manufacturer's protocol.

PPAR binding assay. To test the binding capacity of JWH-015 to PPAR $\gamma$, HeLa cell lines expressing a chimeric protein containing the ligand-binding domain of human PPAR $\gamma$ were used. The ligand-binding domain of PPAR $\gamma$ was fused to the yeast transactivator GAL4 DNA-binding domain. HeLa cells contained a luciferase reporter gene driven by a GAL4 recognition sequence. HeLa cells were treated and binding to PPAR $\gamma$ was estimated according to luciferase activity (relative light units normalized against the reference compound BRL49653).

Oil red o staining. Oil Red $O$ staining was performed after cell treatment with cannabinoids. Briefly, the cells were washed with phosphate-buffered saline twice, 
fixed with $10 \%$ formalin for 30 min, and stained with Oil Red 0 for $1 \mathrm{~h}$. After wash with phosphate-buffered saline, the stained lipid droplets were dissolved in isopropanol and quantified at $540 \mathrm{~nm}$.

Confocal microscopy. After $48 \mathrm{~h}$ in culture, the cells were fixed in $4 \%$ paraformaldehyde in phosphate-buffered saline and incubated. Immunolabelling of neutral lipid with Lipidtox (Invitrogen) was performed by incubation at room temperature for $1 \mathrm{~h}$. Imaging was with a Leica TCS SP5 laser-scanning confocal microscope with LAS-AF imaging software, using a $\times 63$ oil objective.

Cell viability assay. Cells in logarithmic phase were cultured at a density of $5000 \mathrm{cells} / \mathrm{cm}^{2}$ in a 12-well plate. After treatments, as explained in the figure legends, cell viability was assayed by MTT as previously described, ${ }^{19,39}$ to evaluate the effects of cannabinoids on cell growth.

siRNA tranfections. Cells were then transfected in $1 \mathrm{ml}$ OPTIMEN containing $4 \mu \mathrm{g}$ lipofectamine 2000 (Invitrogen), with $100 \mathrm{nM}$ PPAR $\gamma$, AMPK or TRIB3 specific siRNA duplexes (PPAR $\gamma: 5^{\prime}$-CCAAGUUUGAGUUUGCUGUdTdT-3' $3^{\prime}$ and 5'-ACAGCAAACUCAAACUU GGdTdT-3'; AMPK: 5'-CCCAUAUUAUUUGCGUGUAdTdT-3' and 5'-UACACGCCAAAUAAUAUGGGdTdT-3'; TRIB3: 5'-GUGCGAAGCCGCCAC CGUAdTdT-3' and 5'-UACGGUGGCGGCUUCGCACdTdT-3') (Sigma) or control scrambled RNA for $12 \mathrm{~h}$ according to the manufacturer's protocols (Invitrogen). At $24 \mathrm{~h}$ after transfection, the medium was removed and replaced for DMEM containing 10\% fetal bovine serum. At dedicated time points after transfection, cells were used for MTT cell viability assays or western blot.

PPAR gamma expression vector and transient transfections. The PPAR $\gamma$ expression vector pCMX-mPPARg was generously provided by Dr. Mercedes Ricote (CNIC, Madrid, Spain). HepG2 cells were transiently transfected using $4 \mu \mathrm{l}$ Lipofectamine LTX \& Plus Reagent (Invitrogen) with $3 \mu \mathrm{g}$ of the expression vector in 0.2-ml OPTIMEN, according to the manufacturer's protocols (Invitrogen). At $48 \mathrm{~h}$ after transfection, the experiments were performed with the different treatments.

Animal study. Forty-eight (48) male athymic nude (nu/nu) mice aged 5 weeks were purchased from Harlan Iberica Laboratory (Barcelona, Spain) and housed under specific pathogen-free conditions in a 12-h light-dark cycle at $21-23^{\circ} \mathrm{C}$ and $40-60 \%$ humidity. All animal studies were conducted in accordance with the Spanish institutional regulation for the housing, care and use of experimental animals with the approval of the Institutional Animal Care and Use Committee of Alcala University and met the European Community directives regulating animal research. Recommendations made by the United Kingdom Co-ordinating Committee on Cancer Research (UKCCCR) have been kept carefully.

After 1 week adaptation period, mice were injected subcutaneously in the right flank with $10 \times 10^{6} \mathrm{HepG} 2$ cells in $0.1 \mathrm{ml}$ of phosphate-buffered saline $+0.5 \% \mathrm{BSA}$ to induce HCC tumors. Two weeks after transplantation, tumors had grown to an average volume of $150 \mathrm{~mm}^{3}$. Then, the mice were equally divided into six groups $(n=8)$ and daily treated with vehicle, $15 \mathrm{mg} / \mathrm{kg} \mathrm{THC}$ or $1.5 \mathrm{mg} / \mathrm{kg} \mathrm{JWH}-015$ in the presence or absence of $1 \mathrm{mg} / \mathrm{kg}$ GW9662 for 15 days. After treatment, tumors were dissected and weighed.

Statistical analysis. Data are presented as the mean \pm S.E. of the number of experiments indicated. Significance of differences between groups was tested by paired Student's $t$-test using the SPSS statistical software (Chicago, IL, USA). Differences between groups were considered significant when $P<0.05$.

\section{Conclusions}

We here illustrate that the cannabinoids THC and JWH-015 exert antitumor effect against the human $\mathrm{HCC}$ cell lines HepG2 and $\mathrm{HUH}-7$ in vitro and in vivo through PPAR $\gamma$. The activation of PPAR $\gamma$ by cannabinoids is independent of the signaling cascades previously described. However, it links endoplasmic reticulum stress with autophagy. TRIB3 is necessary for PPAR $\gamma$ expression in HCC cells, which collaborates in the autophagy flux.

\section{Conflict of Interest}

The authors declare no conflict of interest.
Acknowledgements. This work has been supported by the Spanish Ministry of Economy and Compentitivity (Grant Minneco BFU2012-31444) Comunidad de Madrid (Grant CAM S2010/BMD-2308) and University of Alcala (Grant GC2011-001). CM has a fellowship from Spanish Foreign Ministry.

1. Alves R. C, Alves D, Guz B, Matos C, Viana M, Harriz M et al. Advanced hepatocellular carcinoma. Review of targeted molecular drugs. Ann Hepatol 2011; 10: 21-27.

2. Waly Raphael S, Yangde Z, Yuxiang C. Hepatocellular carcinoma: focus on different aspects of management. ISRN Oncol 2012; 2012: 421673.

3. Fowler CJ, Gustafsson SB, Chung SC, Persson E, Jacobsson SO, Bergh A. Targeting the endocannabinoid system for the treatment of cancer-a practical view. Curr Top Med Chem 2010; 10: 814-827.

4. Guindon J, Hohmann AG. The endocannabinoid system and cancer: therapeutic implication. Br J Pharmacol 2011; 163: 1447-1463.

5. Velasco G, Sanchez C, Guzman M. Towards the use of cannabinoids as antitumour agents. Nat Rev Cancer 2012; 12: 436-444.

6. O'Sullivan SE. Cannabinoids go nuclear: evidence for activation of peroxisome proliferatoractivated receptors. Br J Pharmacol 2007; 152: 576-582.

7. Pertwee RG, Howlett AC, Abood ME, Alexander SP, Di Marzo V, Elphick MR et al. International Union of Basic and Clinical Pharmacology. LXXIX. Cannabinoid receptors and their ligands: beyond $\mathrm{CB}_{1}$ and $\mathrm{CB}_{2}$. Pharmacol Rev 2010; 62: 588-631.

8. Youssef $\mathrm{J}$, Badr M. Peroxisome proliferator-activated receptors and cancer challenges and opportunities. Br J Pharmacol 2011; 164: 68-82.

9. Yessoufou A, Wahli W. Multifaceted roles of peroxisome proliferator-activated receptors (PPARs) at the cellular and whole organism levels. Swiss Med Wkly 2010; 140: w13071.

10. Zhu Y, Qi C, Korenberg JR, Chen XN, Noya D, Rao MS et al. Structural organization of mouse peroxisome proliferator-activated receptor gamma (mPPAR gamma) gene: alternative promoter use and different splicing yield two mPPAR gamma isoforms. Proc Natl Acad Sci USA. 1995; 92: 7921-7925.

11. Maggiora M, Oraldi M, Muzio G, Canuto RA. Involvement of PPARalpha and PPARgamma in apoptosis and proliferation of human hepatocarcinoma HepG2 cells. Cell Biochem Funct 2010; 28: 571-577.

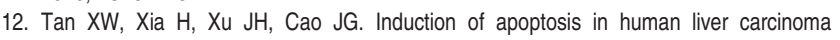
HepG2 cell line by 5-allyl-7-gen-difluoromethylenechrysin. World J Gastroenterol 2009; 15 : 2234-2239.

13. Zhou YM, Wen YH, Kang XY, Qian HH, Yang JM, Yin ZF. Troglitazone, a peroxisome proliferator-activated receptor gamma ligand, induces growth inhibition and apoptosis of HepG2 human liver cancer cells. World J Gastroenterol 2008; 14: 2168-2173.

14. Shen B, Chu ES, Zhao G, Man K, Wu CW, Cheng JT et al. PPARgamma inhibits hepatocellular carcinoma metastases in vitro and in mice. $\mathrm{Br} J$ Cancer 2012 106: 1486-1494.

15. Galli A, Ceni E, Mello T, Polvani S, Tarocchi M, Buccoliero F et al. Thiazolidinediones inhibit hepatocarcinogenesis in hepatitis B virus-transgenic mice by peroxisome proliferatoractivated receptor gamma-independent regulation of nucleophosmin. Hepatology 2010; 52: 493-505.

16. Yu J, Shen B, Chu ES, Teoh N, Cheung KF, Wu CW et al. Inhibitory role of peroxisome proliferator-activated receptor gamma in hepatocarcinogenesis in mice and in vitro. Hepatology 2010; 51: 2008-2019.

17. Schmidt MV, Brune B, von Knethen A. The nuclear hormone receptor PPARgamma as a therapeutic target in major diseases. Sci World J 2010; 10: 2181-2197.

18. Giuliano M, Pellerito O, Portanova $P$, Calvaruso G, Santulli A, De Blasio A et al. Apoptosis induced in HepG2 cells by the synthetic cannabinoid WIN: involvement of the transcription factor PPARgamma. Biochimie 2009; 91: 457-465.

19. Vara D, Salazar M, Olea-Herrero N, Guzman M, Velasco G, Diaz-Laviada I. Anti-tumoral action of cannabinoids on hepatocellular carcinoma: role of AMPK-dependent activation of autophagy. Cell Death Differ 2011; 18: 1099-1111.

20. O'Sullivan SE, Kendall DA. Cannabinoid activation of peroxisome proliferator-activated receptors: potential for modulation of inflammatory disease. Immunobiology 2010; 215: 611-616.

21. Burns KA, Vanden Heuvel JP. Modulation of PPAR activity via phosphorylation. Biochim Biophys Acta 2007; 1771: 952-960.

22. Takahashi $Y$, Ohoka N, Hayashi H, Sato R. TRB3 suppresses adipocyte differentiation by negatively regulating PPARgamma transcriptional activity. J Lipid Res 2008; 49: 880-892.

23. Zhou J, Zhang W, Liang B, Casimiro MC, Whitaker-Menezes D, Wang $M$ et al. PPARgamma Activation Induces Autophagy in Breast Cancer Cells. Int J Biochem Cell Biol 2009; 41: 2334-2342.

24. Jiang M, Fernandez S, Jerome WG, He Y, Yu X, Cai H et al. Disruption of PPARgamma signaling results in mouse prostatic intraepithelial neoplasia involving active autophagy. Cell Death Differ 2010; 17: 469-481.

25. Salazar M, Carracedo A, Salanueva IJ, Hernandez-Tiedra S, Lorente M, Egia A et al. Cannabinoid action induces autophagy-mediated cell death through stimulation of ER stress in human glioma cells. J Clin Invest 2009; 119: 1359-1372.

26. Mahmood DF, Jguirim-Souissi I, Khadija el H, Blondeau N, Diderot V, Amrani S et al. Peroxisome proliferator-activated receptor gamma induces apoptosis and inhibits autophagy of human monocyte-derived macrophages via induction of cathepsin L: potential role in atherosclerosis. J Biol Chem 2011; 286: 28858-28866. 
27. Nakken B, Varga T, Szatmari I, Szeles L, Gyongyosi A, Illarionov PA et al. Peroxisome proliferator-activated receptor gamma-regulated cathepsin $D$ is required for lipid antigen presentation by dendritic cells. J Immunol 2011; 187: 240-247.

28. Turk B, Bieth JG, Bjork I, Dolenc I, Turk D, Cimerman N et al. Regulation of the activity of lysosomal cysteine proteinases by $\mathrm{pH}$-induced inactivation and/or endogenous protein inhibitors, cystatins. Biol Chem Hoppe Seyler 1995; 376: 225-230.

29. Yu J, Qiao L, Zimmermann L, Ebert MP, Zhang H, Lin W et al. Troglitazone inhibits tumo growth in hepatocellular carcinoma in vitro and in vivo. Hepatology 2006; 43: 134-143.

30. Yoshizawa K, Cioca DP, Kawa S, Tanaka E, Kiyosawa K. Peroxisome proliferatoractivated receptor gamma ligand troglitazone induces cell cycle arrest and apoptosis of hepatocellular carcinoma cell lines. Cancer 2002; 95: 2243-2251.

31. Koga H, Sakisaka S, Harada M, Takagi T, Hanada S, Taniguchi E et al. Involvement of p21(WAF1/Cip1), p27(Kip1), and p18(INK4c) in troglitazone-induced cell-cycle arrest in human hepatoma cell lines. Hepatology 2001; 33: 1087-1097.

32. Rumi MA, Sato H, Ishihara S, Kawashima K, Hamamoto S, Kazumori H et al. Peroxisome proliferator-activated receptor gamma ligand-induced growth inhibition of human hepatocellular carcinoma. Br J Cancer 2001; 84: 1640-1647.

33. Toyoda M, Takagi H, Horiguchi N, Kakizaki S, Sato K, Takayama H et al. A ligand for peroxisome proliferator activated receptor gamma inhibits cell growth and induces apoptosis in human liver cancer cells. Gut 2002; 50: 563-567.

34. Sozio MS, Lu C, Zeng Y, Liangpunsakul S, Crabb DW. Activated AMPK Inhibits PPAR alpha\} and PPAR \{gamma\} Transcriptional Activity in Hepatoma Cells. Am J Physio Gastrointest Liver Physiol 2011; 301: G739-G747.
35. Salazar M, Carracedo A, Salanueva IJ, Hernandez-Tiedra S, Egia A, Lorente M et al. TRB3 links ER stress to autophagy in cannabinoid anti-tumoral action. Autophagy 2009; 5 : 1048-1049.

36. Salazar M, Hernandez-Tiedra S, Torres S, Lorente M, Guzman M, Velasco G. Detecting autophagy in response to ER stress signals in cancer. Methods Enzymol 2011; 489: 297-317.

37. Wang J, Lv XW, Shi JP, Hu XS. Mechanisms involved in ceramide-induced cell cycle arrest in human hepatocarcinoma cells. World J Gastroenterol 2007; 13: 1129-1134.

38. Sanchez AM, Martinez-Botas J, Malagarie-Cazenave S, Olea N, Vara D, Lasuncion MA et al. Induction of the endoplasmic reticulum stress protein GADD153/ CHOP by capsaicin in prostate PC-3 cells: a microarray study. Biochem Biophys Res Commun 2008; 372: 785-791.

39. Malagarie-Cazenave S, Olea-Herrero N, Vara D, Diaz-Laviada I. Capsaicin, a component of red peppers, induces expression of androgen receptor via PI3K and MAPK pathways in prostate LNCaP cells. FEBS Lett 2009; 583: 141-147.

Cell Death and Disease is an open-access journal published by Nature Publishing Group. This work is licensed under a Creative Commons Attribution-NonCommercialNoDerivs 3.0 Unported License. To view a copy of this license, visit http://creativecommons.org/licenses/by-nc-nd/3.0/ 